\title{
Interseasonal variation in the transport of pilchard eggs and larvae off southern Western Australia
}

\author{
W. J. Fletcher, R. J. Tregonning, G. J. Sant \\ Bernard Bowen Fisheries Research Institute, W.A. Marine Research Laboratories, PO Box 20, North Beach, \\ 6020 Western Australia, Australia
}

\begin{abstract}
The distribution and relative abundance of pilchard Sardinops sagax neopilchardus eggs and larvae along the south coast of Western Australia were determined in July and December 1991. In July, there were 2 sites of spawning activity; large numbers of Day 1 eggs were found along the inner shelf region, 2 to $6 \mathrm{~km}$ from the coast off the King George Sound region of Albany, with a further peak in the inner and mid shelf regions off Bremer Bay, $150 \mathrm{~km}$ east of Albany. Almost no eggs were found in the area west of Albany where the seasonally strong, eastwards-flowing Leeuwin Current was located close to the coastline. The peak in the concentration of Day 2 eggs was located some $40 \mathrm{~km}$ east of Albany, with peaks in the abundance of the yolk-sac and post-larvae found 100 and $150 \mathrm{~km}$ east of Albany, respectively. This variation in the location of the different pilchard stages was consistent with an eastwards transport rate of 0.5 to 1.0 knots. By contrast, in December, when the Leeuwin Current was weak, there was no evidence of unidirectional transport with the peaks in the abundance of all pilchard stages located in the Albany region. The influences of the variation in transport between spawning seasons on the structure of pilchard stocks in this area and the implications for the management of the fisheries in this region are discussed. The value of using several boats for simultaneous sampling to provide a 'snapshot picture' is demonstrated. A comparison of plankton towing methods showed higher relative catch rates for Day 1 pilchard eggs using vertical compared with oblique tows, with the reverse found for Day 2 eggs.
\end{abstract}

KEY WORDS: Ichthyoplankton - Sardinops sagax neopilchardus · Pilchards - Spawning - Advection . Oceanographic fronts · Leeuwin Current · Western Australia

\section{INTRODUCTION}

The location and timing of spawning in relation to oceanographic features can greatly affect the management of a fishery by influencing both the complexity of the population structure and variations in stock size. Significantly, the area of spawning for many small pelagic species often coincides with major current systems (Norcross \& Shaw 1984). The extent to which the transport of eggs and larvae by these currents, followed by subsequent return adult migration, can generate separate adult populations has been vigorously debated (Iles \& Sinclair 1982, Cushing 1988, 1990, Sinclair 1988, Heath 1992). There is strong evidence, however, that the strength or path of currents can influence subsequent year class strength (e.g. Nelson et al. 1977, Kasai et al. 1992) or even result in substantial expansion or contraction of a species range (e.g. sardines; Kondo 1988). Consequently, investigation of oceanographic influences on spawning dynamics is now a major focus of research for many exploited species (Moser \& Smith 1993).

The sardine/pilchard Sardinops sagax neopilchardus fishery along the south coast of Western Australia is currently the largest volume scale-fishery of the state. The annual catch, which was less than $1000 \mathrm{t}$ prior to 1980 , approached $10000 \mathrm{t}$ in 1991 , with up to 40 purse-seine boats licensed to fish in 6 locations (Fletcher 1991). This increase in effort has been accompanied by management concerns that the present 
rate of exploitation may be too high, especially in the Albany area where the majority of the catch is taken. There is also conflict among the fishermen at the different locations along the coast regarding the potential impact each group has on the stock. Insufficient knowledge of the distribution and migration of pilchards in this region, and in particular the level of stock separation, make it difficult to resolve this problem. Unfortunately, the examination of adults using morphometric and trace metal analyses has resulted in conflicting conclusions regarding the degree of stock separation (Syahailatua 1992, Edmonds et al. 1994).

The major oceanographic influence along the southern coast of Western Australia is the seasonally and annually variable, eastwards-flowing Leeuwin Current. This current, which originates off the north-west coast and consists of oligotrophic tropical water, flows most strongly during the autumn/winter period (April-September; Cresswell 1991, Pearce 1991). It is generally located on or near the edge of the continental shelf which is at its narrowest off Albany and could, therefore, greatly affect both the location of pilchard spawning, by the influence of temperature fronts (e.g. Nakata et al. 1989), and the subsequent transport (advection) of the planktonic pilchard eggs when released.

Previous research (Fletcher \& Tregonning 1992) has shown that there are 2 major periods of pilchard spawning activity in the Albany region each year, winter and summer, with the peak months within these seasons being July and December, respectively. Most spawning occurred at night and on the inner half of the continental shelf, inside the main influence of the

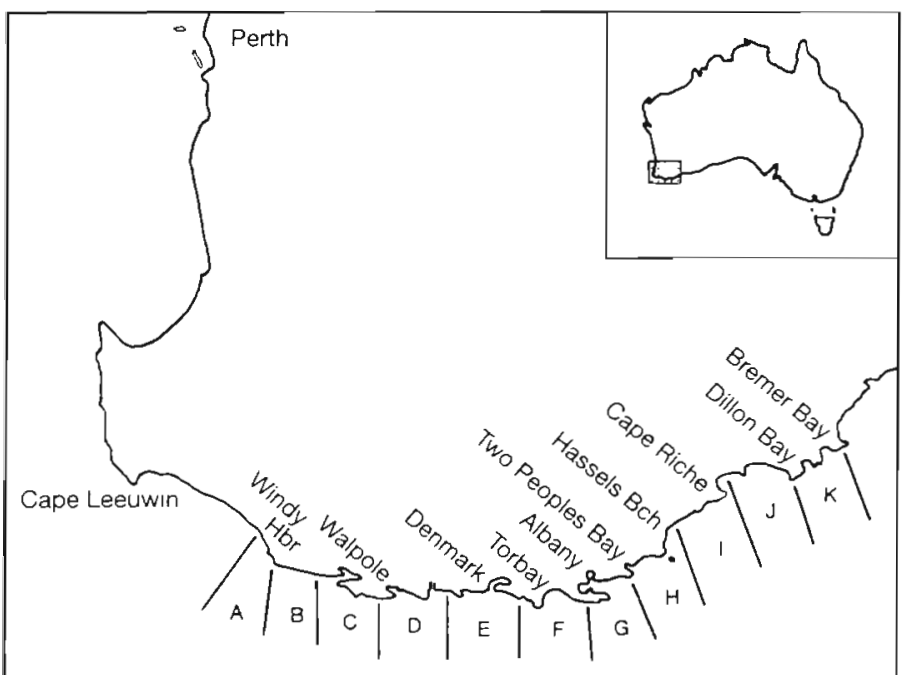

Fig. 1. Southern Western Australia showing the plankton sampling blocks (A to K)
Leeuwin Current (Fletcher \& Tregonning 1992). The small section of the coast that was sampled in that study, however, prevented any assessment of the level of transport of eggs and larvae away from the region. It is likely, however, that the seasonal cycle in Leeuwin Current strength may have an affect on both the location of pilchard spawning and the rates of egg transport in each of the 2 spawning seasons. The level of transport and any seasonal variation may influence the population structure of pilchards along the south coast of Western Australia.

The objectives of the present study were to determine the spatial pattern and relative abundance of pilchard eggs and larvae along the south coast of Western Australia during the 2 peak spawning months, July and December, in relation to the position and strength of the Leeuwin Current. Information on the locations and intensity of pilchard spawning across the south coast of Western Australia and the subsequent movement of the eggs and larvae is necessary to develop an understanding of the structure of this stock. This survey has also been designed to provide data to test some of the hypotheses on adult distribution suggested by a spatial model of the Albany fishery (Fletcher 1992).

\section{METHODS}

Plankton sampling locations. Samples were taken along the south coast of Western Australia between Bremer Bay $\left(34.26^{\circ} \mathrm{S}, 119.36^{\circ} \mathrm{E}\right)$ and Windy Harbour $\left(34.43^{\circ} \mathrm{S}, 115.51^{\circ} \mathrm{E}\right)$. The coast in this area was divided into 11 sampling blocks, each approximately $40 \mathrm{~km}$ across (Fig. 1). Nine of these (Blocks B to J) corresponded to the spatial zones defined in the simulation model developed for the fishery in the Albany region (see Fletcher 1992 for details).

In each block during July 1991, there were 2 sampling sites at both 7 and $11 \mathrm{~km}$ from the coast, in the inner shelf (IS) region (Fletcher \& Tregonning 1992). Additionally, there were 2 mid-shelf (SH) locations in each block $22 \mathrm{~km}$ from the coast. In 6 of the blocks there were 2 locations that were only 2 to $4 \mathrm{~km}$ from the coast (outer bay, OB), generally offshore of embayments. Finally, off Bremer Bay, there were 2 sites $35 \mathrm{~km}$ from the coast, near the edge of the shelf (outer shelf, OS) (Fig. 2a).

During December 1991, the area of sampling was reduced to locations within blocks $\mathrm{D}$ to $\mathrm{K}$ because of logistic constraints. Furthermore, samples were only taken in the inner shelf (IS) region with 3 sites at both 6 and $15 \mathrm{~km}$ from the coast per block (Fig. 2b). 

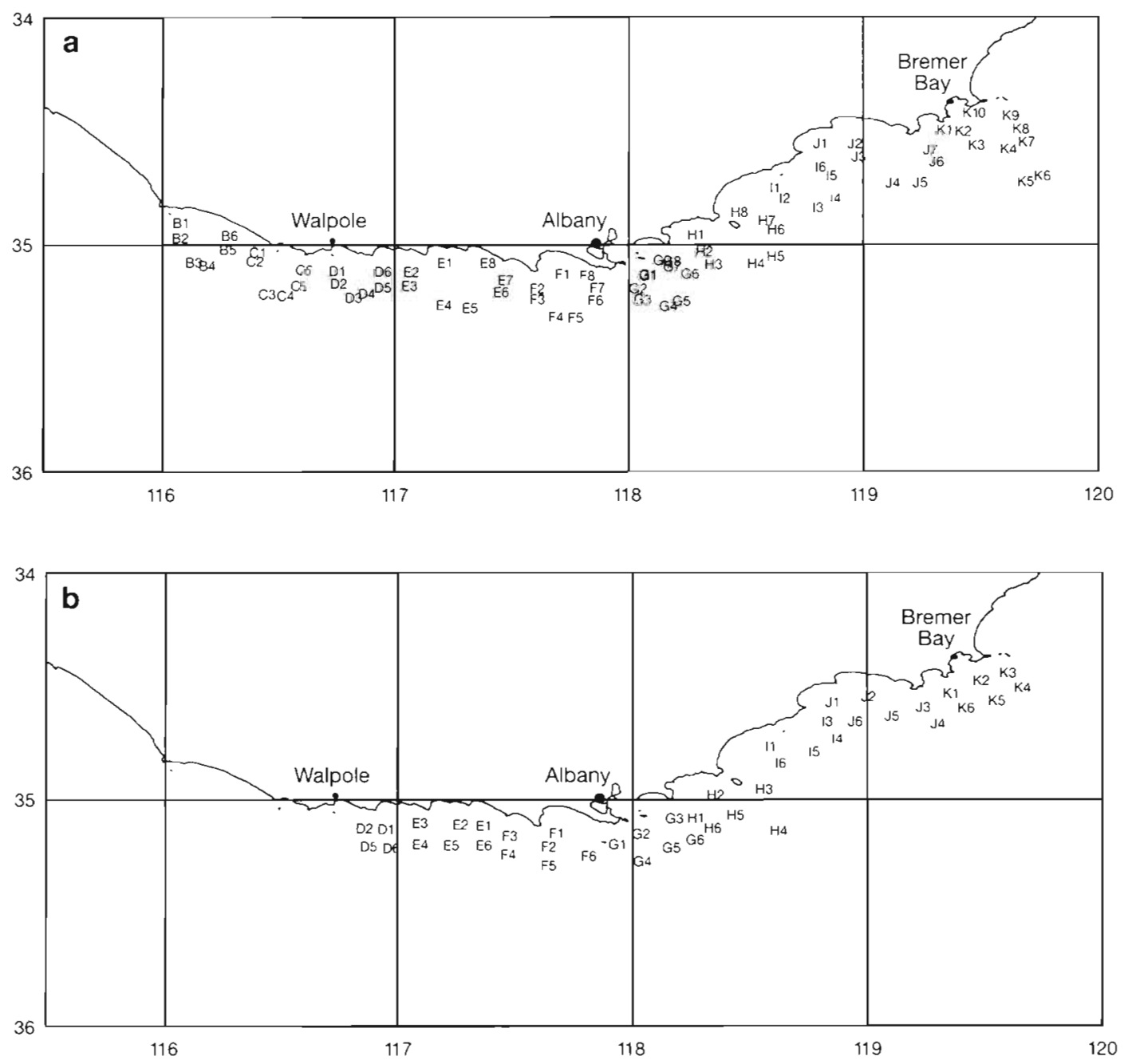

Fig. 2. The south coast region of Western Australia showing the main plankton tow locations in (a) July and (b) December 1991. Longitudes and latitudes are degrees east and south respectively

Tow methods. A number of boats (local pilchard or tuna fishing boats plus smaller boats) were used in order to complete the survey in the shortest possible time. Up to 3 boats operated each day, one east of Albany, one west of Albany and a third in the area immediately off Albany sampling the same locations over a number of days. The plankton tows were completed between 05:00 and 20:10 $\mathrm{h}$, with the majority completed between 08:00 and 14:00 h. The sampling gear consisted of two $500 \mu \mathrm{m}$ nylon mesh nets each with a mouth diameter of $60 \mathrm{~cm}$ combined to form a standard double bongo arrangement (Smith \& Richardson 1977). Each net had a hard cod-end of $90 \mathrm{~mm}$ PVC tube with 2 circular ports covered by $500 \mu \mathrm{m}$ mesh. Flow meters (Rigosha Company, or General Oceanics) were suspended in the mouth of one of the nets, and readings taken at the end of each tow for the subsequent calculation of volume filtered. During
July, all tows were double oblique and made to a depth of at least $50 \mathrm{~m}$ at a speed of approximately $1 \mathrm{~m} \mathrm{~s}^{-1}$. Each tow took a total of $7 \mathrm{~min}$ and each net filtered on average $100 \mathrm{~m}^{3}$ of water. The contents of the 2 nets were combined for analyses.

During December, oblique tows were completed at only 4 of the 6 stations in each block, whereas vertical tows were undertaken at 46 of the 47 stations. For the vertical tows, the net was lowered to a set length of rope $(50 \mathrm{~m}), 1 \mathrm{~min}$ was allowed for the net to sink and then it was hauled back to the surface at a speed of $1 \mathrm{~m}$ $\mathrm{s}^{-1}$. This took a further minute to complete with each net on average filtering $22 \mathrm{~m}^{3}$ of water. The vertical and oblique tows undertaken at the same sites were completed consecutively (i.e. not simultaneously), the order varying randomly.

Samples were immediately preserved in a buffered $5 \%$ formalin solution and were transferred to a $3 \%$ 
formalin solution within a few weeks of collection. At each sampling location the surface water temperature was measured with a mercury thermometer and a sample of water was collected for the later determination of salinity with a Yeo-Kal Temperature salinity bridge

Plankton sorting. The settled volume of the collected material was determined using a $100 \mathrm{ml}$ measuring cylinder. All pilchard eggs and larvae were removed from the sample and stored. In samples where the numbers of pilchard eggs were large (>1000), only a subsample of the material was sorted, and the total numbers scaled accordingly. Egg and larval abundance for the samples was estimated as the number per $200 \mathrm{~m}^{3}$ (100 $\mathrm{m}^{3}$ for each net).

The stage of development for each pilchard egg was determined using the criteria developed by Baker (1972) and the additional opaque stages, representing dead eggs (Fletcher \& Tregonning 1992). Using the average speed of development for pilchard eggs at $18^{\circ} \mathrm{C}$ for July and $19^{\circ} \mathrm{C}$ for December (from King 1977), we assumed that all eggs less than stage 7 were spawned the night previous to capture. Similarly, all eggs greater than stage 9 were assumed to have been spawned 2 nights previous to capture; those between stages 7 and 8 were classified as Day 1 or Day 2 eggs depending upon the time of capture $(<15: 00 \mathrm{~h}$, Day 2 ; $>$ 15:00 h, Day 1). Abundance calculations were made of the abundance of total pilchard eggs and pilchard eggs spawned 1 night and 2 nights previous to the time of capture.

The length of each pilchard larva collected in the samples was measured with the aid of a video camera attached to a binocular microscope. The images of each of the larvae (which were mostly curled or bent in shape and therefore difficult to measure using an eyepiece micrometer) were measured on a television screen using a length of flexible plastic which was bent to fit the shape of each larva. The larval length was then determined to the nearest $0.5 \mathrm{~mm}$.

The larvae were separated into 3 classes based on their length and visible structure using the results of studies by Baker (1972) and King (1977). Yolk-sac larvae were generally less than $6 \mathrm{~mm}$; early post-larvae were 6 to $10 \mathrm{~mm}$; and late stage post-larvae were defined as those larger than $10 \mathrm{~mm}$. Indices of abundance were calculated for each of these 3 larval groups.

Statistical analyses. Statistical analysis of the abundance of pilchard eggs among sampling blocks were made using analyses of variance (SAS Proc GLM procedure; SAS Inst. 1987), whereby the factors were the blocks along the coast and, in July, the 3 regions within each block (OB, IS and SH). Cochrans' test for homogeneity of the variances was performed on the vari- ances, with $\log$ transforms being applied to the data before analysis. Comparisons between samples taken at the same site on different days and on the same day using oblique and vertical tows were made using paired t-tests.

\section{RESULTS}

\section{July 1991 survey}

A total of 90 plankton samples were taken during July 1991 . Within the main period of sampling (25 to 29 July 1991), all stations in the south coast grid (except for those in block A) were sampled at least once, resulting in a total of 77 locations being sampled. Most of the additional tows were in the King George Sound area, with Sites G1 and G8 sampled on consecutive days from 25 to 29 July and on 3 additional days prior to this period.

\section{Pilchard egg distribution}

Pilchard eggs were found at 48 of the 77 stations with abundances for many samples being in excess of 1000 eggs (per $200 \mathrm{~m}^{3}$ ) and with one sample exceeding 8000 (Fig. 3a). The mean abundance of pilchard eggs for all 77 stations was 319 . Samples with large numbers of eggs were mainly clustered around the Albany and Two Peoples Bay region. Consistent but smaller numbers of eggs were found for most samples east of Two Peoples Bay through to Bremer Bay. By contrast, west of Torbay no pilchard eggs were found, except for one sample off Walpole.

Egg abundance and water temperature. The majority of eggs, and the majority of samples with eggs, were found at water temperatures between 17.5 and $18.5^{\circ} \mathrm{C}$ (Fig. $4 \mathrm{a}$ ). The mean temperature for the location of the eggs was $18^{\circ} \mathrm{C}$. There was some evidence that spawning was not occurring in water warmer than $18.5^{\circ} \mathrm{C}$ because the percentage of samples in each temperature class containing eggs dropped rapidly for stations above this temperature (Fig. 4a).

Egg staging. The distribution of egg stages found in the samples formed a bimodal distribution (Fig. 4b), with a peak at egg stage 6 and a further peak at egg stages $11 \& 12$. This distribution supported the assumed cut-off points between Day 1 and Day 2 eggs using the development rate at $18^{\circ} \mathrm{C}$.

Normal (not opaque) Day 2 eggs made up a much larger proportion of the eggs collected (57\%) than did Day 1 eggs ( $24 \%$ ). Opaque (dead) eggs made up a significant part of the samples, comprising almost $20 \%$ of the total eggs captured. In contrast to the normal eggs, 

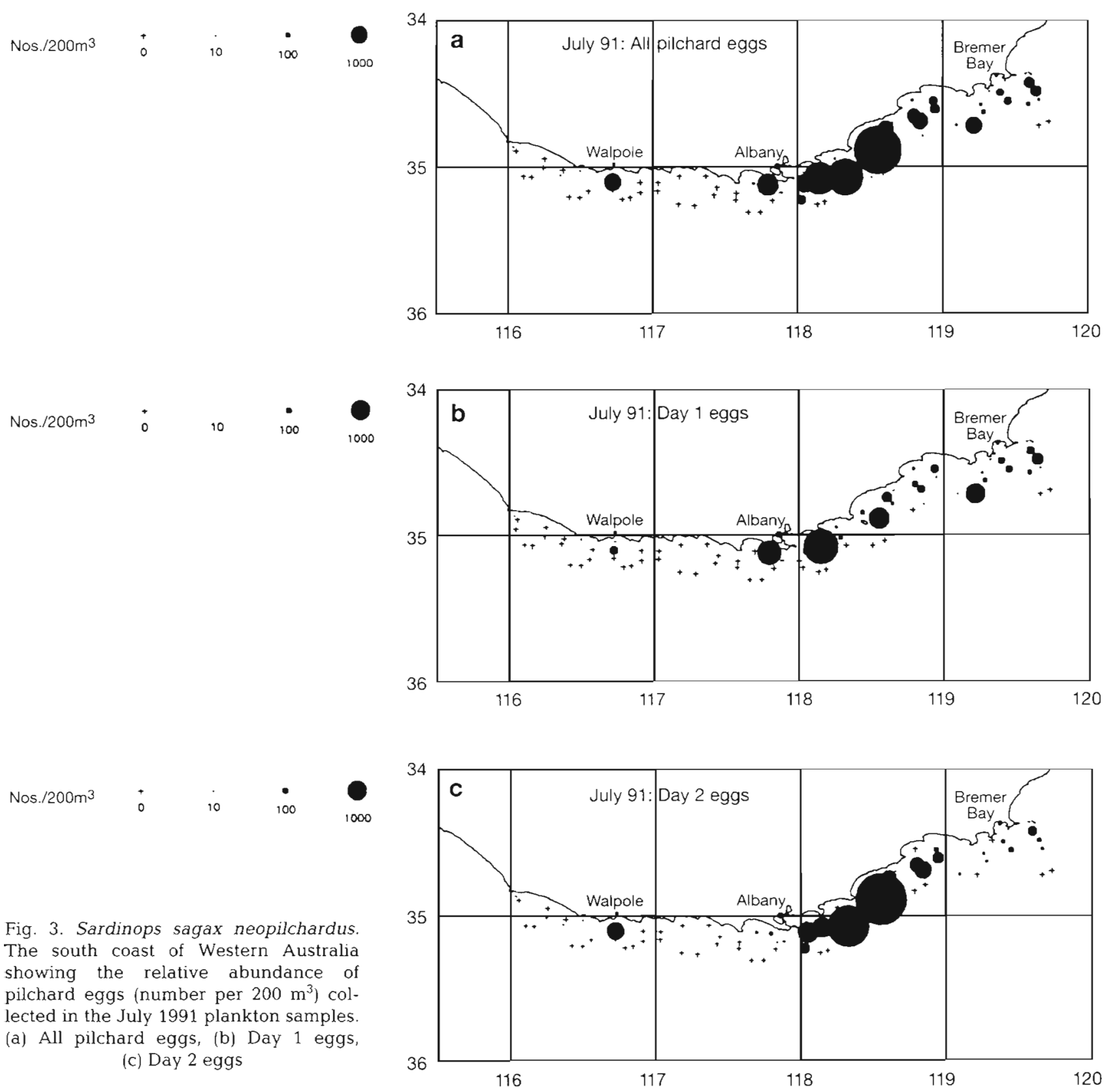

there were far more opaque eggs with stages less than 6 than those with older stages (Fig. 4b).

Day 1 eggs. Thirty-eight of the 77 samples contained Day 1 pilchard eggs, with an overall mean abundance of 138 (coefficient of variation, $\mathrm{CV}=3.21$ ). For this stage there appeared to be 2 regions of higher abundance, one in the inner shelf region from Torbay to Two Peoples Bay, and a second peak over a more widespread area off Dillon Bay and Bremer Bay (Fig. $3 b)$. The mean concentration for Day 1 eggs in each area is plotted in Fig. 5a which indicates that there are 3 separate zones of egg abundance. The area west of
Torbay (block F) had basically no Day 1 eggs except for one site off Walpole (block D). There were, however, 2 peaks in abundance, one in block $G$ (Albany) and another minor peak in block $\mathrm{J}$ (Dillon Bay).

A 2-factor unbalanced analysis of variance confirmed that there were significant differences both among the blocks along the coast and between regions within a block (Table 1). Examination of the means (Fig. 5a) showed that the largest means were in the King George Sound (G, H) and Bremer Bay ( $J, K$ ) regions. There was also a significant difference in the offshore extent of pilchard spawning, the 2 inner sam- 

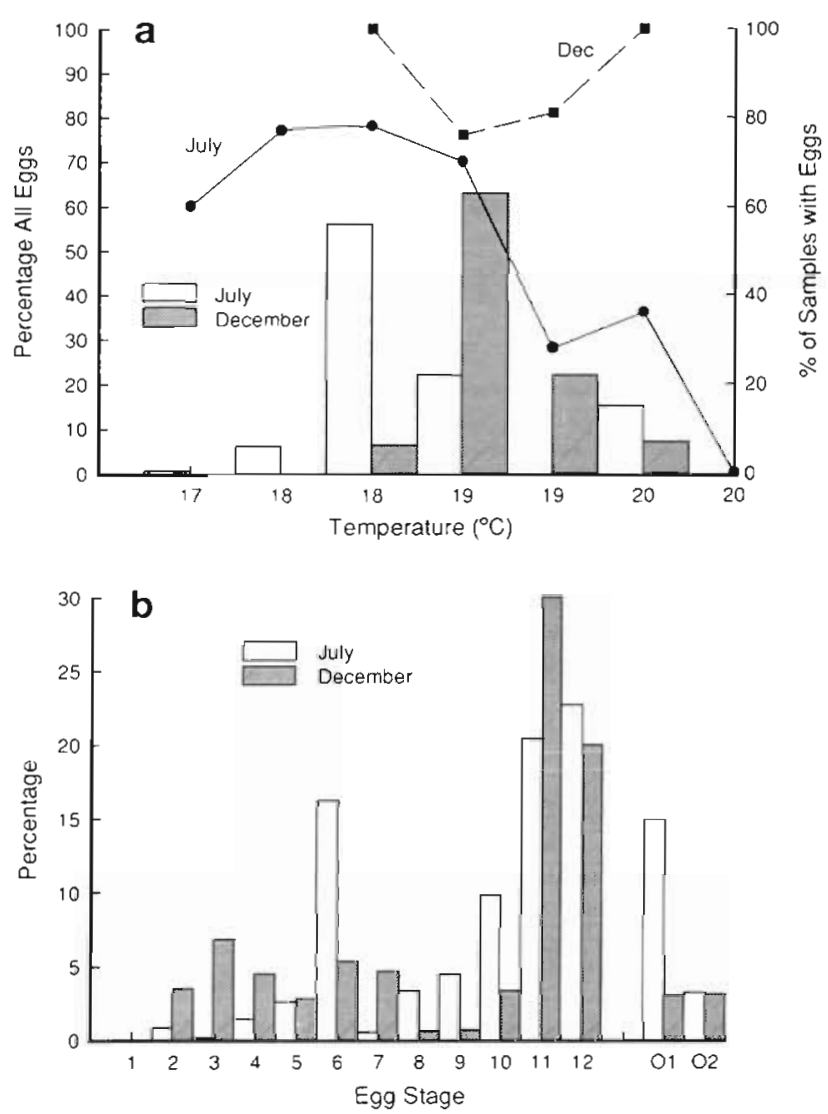

Fig. 4. Sardinops sagax neopilchardus. (a) The presence of pilchard eggs both as a percentage of all eggs captured (bars) and the percentage of samples containing pilchard eggs (lines) as a function of sea surface temperature. (b) Development stages ( 1 to 12) of the pilchard eggs as defined by Baker (1972) and Fletcher \& Tregonning (1992). O1 and O2 refer to opaque (dead) eggs between stages 1 to 6 and stages 7 to 12 respectively

pling regions of the inner shelf (IS) and outer bay (OB) had larger abundances of eggs than the offshore areas of the mid shelf ( $\mathrm{SH}$ ) and the outer shelf region (OS) offshore of Bremer Bay (Fig. 3b).

Day 2 eggs. Forty samples contained Day 2 eggs, with an overall mean abundance of $184(\mathrm{CV}=3.00)$. The distribution of Day 2 eggs also showed clumping, but the largest numbers of eggs were found off the Two Peoples Bay and Hassels Beach areas (Fig. 3c). Unlike Day 1 eggs, the mean concentration of this group had only a single peak in its distribution, in block H (Fig. 5b). An analysis of variance for this group also indicated significant differences among samples but there was a significant interaction between area and region. This arose from most Day 2 eggs being restricted to the inner shelf regions within blocks $\mathrm{H}$ and I but many were found in the mid-shelf regions east of Cape Riche, in blocks J and K.
Table 1. Two-factor analysis of variance using a log transformation on the abundance of Day 1 eggs at the 10 blocks along the coast $(B$ to $K$ ) and the 3 regions within each block (OB IS, SH) sampled during July 1991 ns: $p>0.05 ; " p<0.05$; " p $<0.01$

\begin{tabular}{lrrrl|}
\cline { 1 - 2 } Source & df & \multicolumn{1}{c}{ SS } & MS & $F$ \\
\cline { 1 - 2 } Block & 9 & 29.74 & 3.3 & $4.9 \cdot$ \\
Region & 2 & 5.32 & 2.6 & $4.02 \cdot$ \\
Block $\times$ Region & 14 & 12.68 & 0.9 & $1.37 \mathrm{~ns}$ \\
Residual & 45 & 29.81 & 0.66 & \\
\hline
\end{tabular}

Pilchard larval distribution

These were found in most of the plankton samples taken during July 1991 (63 of 77) with an overall mean abundance of 80 . The distribution of the larvae was found to be more easterly than that of the eggs, with large numbers only found east of Hassels Beach (Fig. 6a).

Yolk-sac larvae. These larvae, which represent the stage approximately 3 to $4 \mathrm{~d}$ after spawning, were only present in 33 samples with a mean of $46(\mathrm{CV}=2.86)$. They were distributed from Hassels Beach to Bremer Bay (Fig. 6b) with the maximum abundance in block I (Fig. 5c).

Early post-larvae. This larval group, which is between 5 and $8 \mathrm{~d}$ post-spawning, was found in 55 samples, generally at low numbers with an overall mean abundance of 33 ( $\mathrm{CV}=2.80$; Fig. 6c). The largest numbers of these larvae were found in the Bremer Bay region with the peak in abundance being block K (Fig. 5d).

Late stage post-larvae (greater than 1 wk old). These were found in very low numbers (mean $=1.0$ ) except for one sample in Bremer Bay itself. There was no consistent pattern or peak in abundance of this group, at least within the area sampled during this study

\section{December 1991 survey}

A total of 47 sites were sampled between 11 and 13 December with over 70 samples completed. These comprised 27 oblique tows and 46 vertical tows. In addition, sampling in the region offshore of King George Sound was completed each day during this period

\section{Pilchard eggs}

These were found at a total of 41 sites with the abundance of eggs exceeding 1000 per $200 \mathrm{~m}^{3}$ in only 1 sample. The mean abundance of eggs for all 47 sites 
July
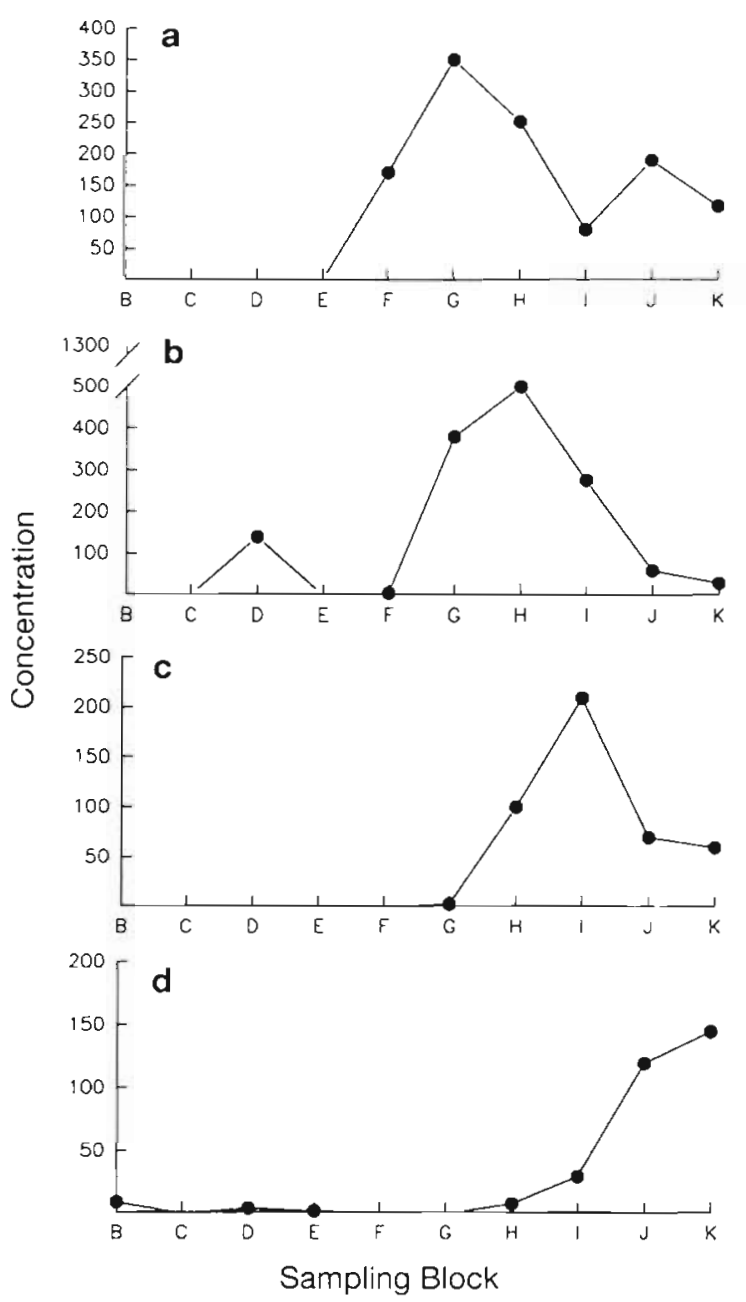

December
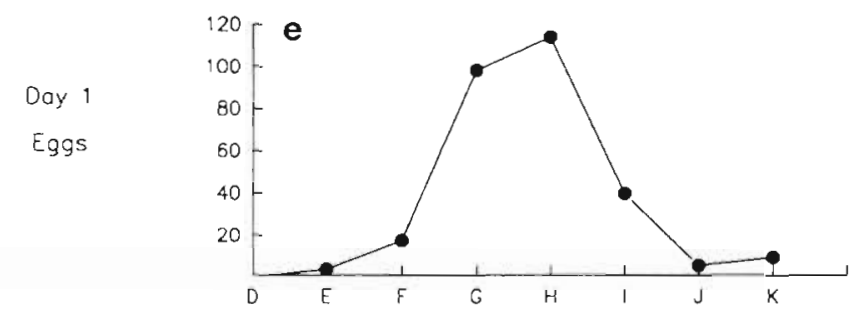

Day 2

Eggs

Yolk-Soc

Lorvae
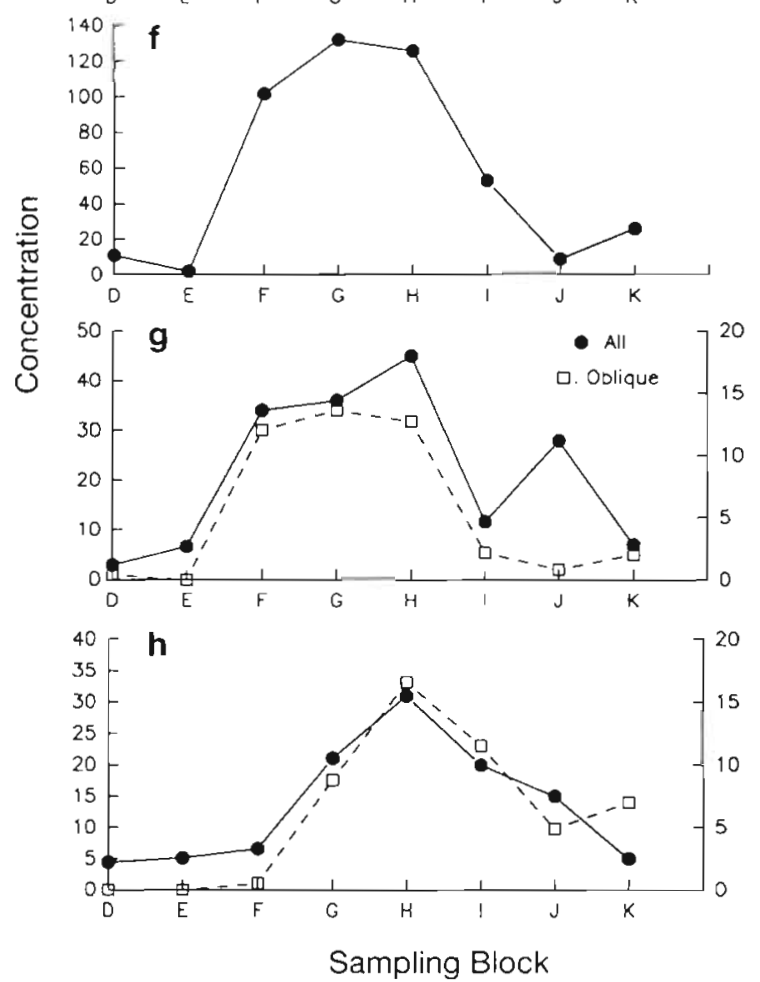

Fig. 5. Sardinops sagax neopilchardus. The mean abundance (number per $200 \mathrm{~m}^{3}$ ) of 4 different planktonic stages of pilchards in July 1991: (a) Day 1 eggs, (b) Day 2 eggs, (c) yolk-sac larvae and (d) post-larvae, and in December 1991: (e) Day 1 eggs, (f) Day 2 eggs, (g) yolk-sac larvae and (h) post-larvae, in each of the 10 blocks along the south coast region. Right-hand axis in (g) and (h) refers to the oblique tows

was 98 with the eggs distributed throughout the entire sampling region from Walpole in the west through to Bremer Bay in the east with no major discontinuities (Fig. 7a).

Egg abundance and water temperature. The range of water temperatures encountered during this period was not large $\left(17.9\right.$ to $\left.20.5^{\circ} \mathrm{C}\right)$ with $90 \%$ of readings between 18 and $19.5^{\circ} \mathrm{C}$. The majority of eggs were found in water with a temperature of $18.5^{\circ} \mathrm{C}$ with the mean temperature for the samples with eggs being $18.8^{\circ} \mathrm{C}$ (Fig. 4a). The percentage of samples in which eggs were present was relatively high at all temperatures (Fig. 4a), with little evidence of a preference for any temperature.

Egg staging. There were 2 modes in the stages of eggs found during December (Fig. 4b). These centred on stages 4 to 6 and stages 11 and 12. The cut-off point between Day 1 and Day 2 eggs was stage 8 which is consistent with development rates at the mean temperature found during the series.

Eggs. A total of 32 of the 47 sites contained Day 1 eggs with an overall mean abundance of $38(\mathrm{CV}=2.4)$. The Day 1 eggs had an extensive distribution, with small numbers of eggs found throughout the sampling area and the highest numbers found on either side of King George Sound (Fig. 7b).

The analysis of variance (Table 2) indicates that there was a significant difference in abundance amongst sampling blocks, with the mean concentration for Day 1 eggs at a maximum in the region between Torbay and Hassels Beach (blocks G, H, I; Fig. 5e). 


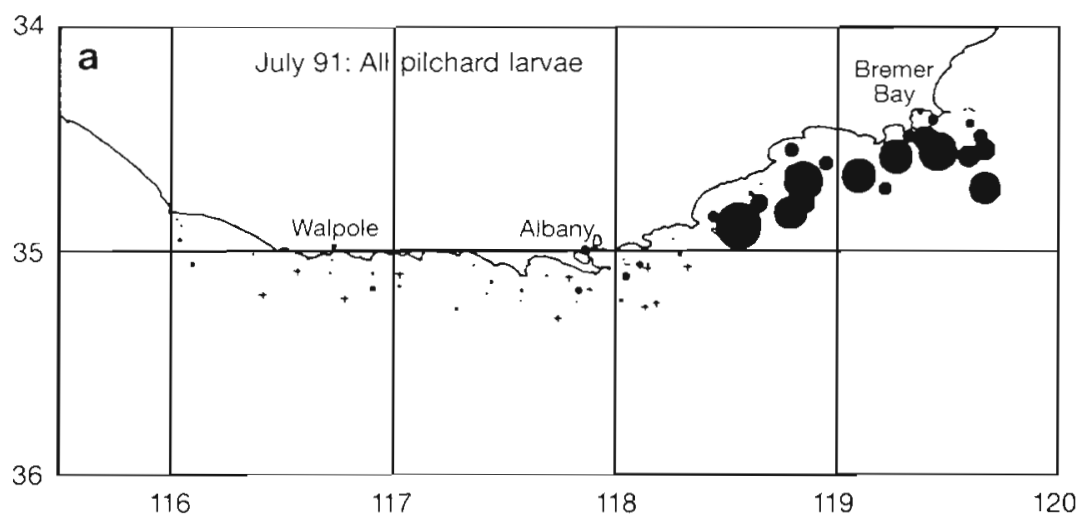

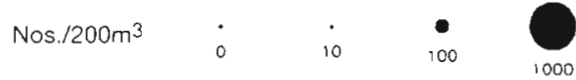
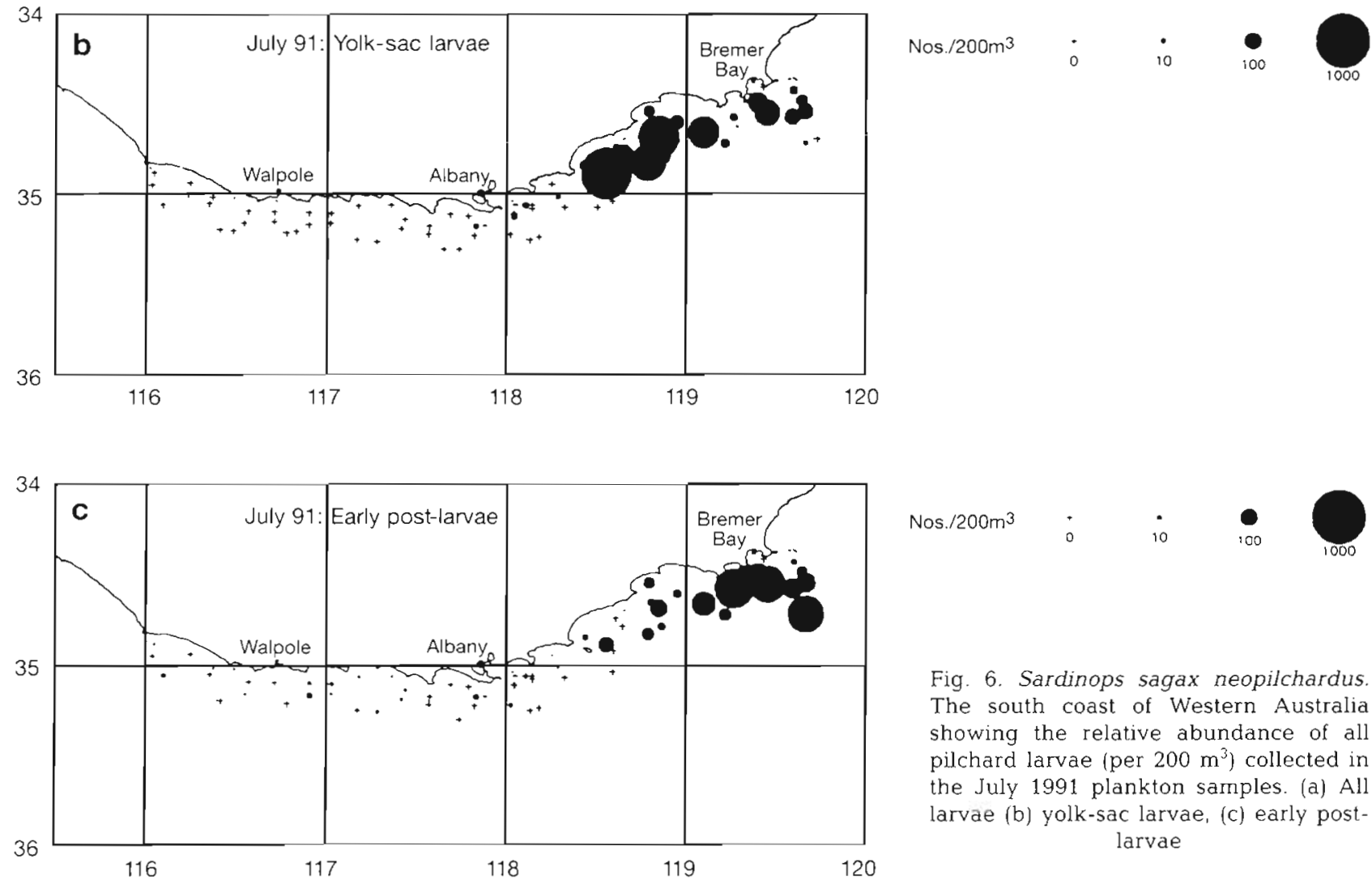

Nos. $/ 200 m^{3}$

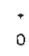

Fig. 6. Sardinops sagax neopilchardus The south coast of Western Australia showing the relative abundance of all pilchard larvae (per $200 \mathrm{~m}^{3}$ ) collected in the July 1991 plankton samples. (a) All larvae (b) yolk-sac larvae, (c) early postlarvae

There were Day 2 eggs at 37 of the 47 sites with a mean overall abundance of $61(\mathrm{CV}=2.0)$. The distribution of these eggs during this period virtually mirrored that of the Day 1 eggs (Fig. $7 \mathrm{C}$ ). An analysis of variance indicated that there were significant differences among sites $(F=2.9, \mathrm{df}=7,39 ; \mathrm{p}<0.05)$, with the major groups still including the blocks from west of Torbay to Hassels Beach (F, G, H, I, Fig. 5f). Thus, the mean concentration of Day 2 eggs is centred in a similar position to that of Day 1 eggs but slightly more dispersed.

\section{Pilchard larvae}

These were found at most sites taken during this period (Fig. 8a). Both yolk-sac and early post-larvae had the heaviest concentrations located off the Albany region (blocks $\mathrm{F}, \mathrm{G}, \mathrm{H}$; Fig. $5 \mathrm{~g}$, h) with mean concentrations of $19.2(\mathrm{CV}=1.5)$ and $12.8(\mathrm{CV}=1.4)$ respectively. Late post-larvae were only found in 9 of the 48 sampling locations, with most of these still located offshore of Albany (Fig. 8d). 

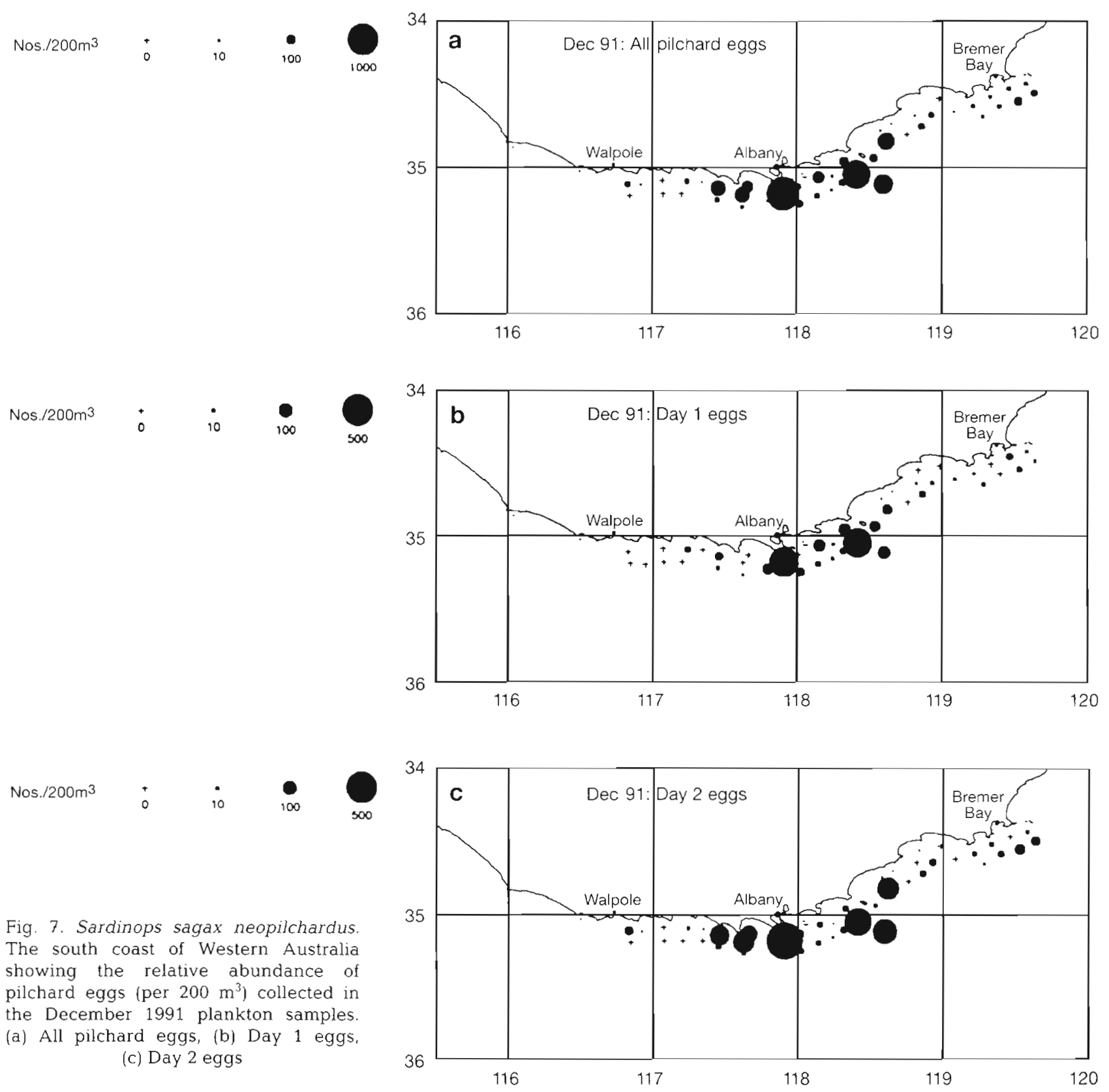

\section{Consistency of sampling}

A number of tests of the repeatability and reliability of these plankton sampling techniques as measures of the distribution and abundance of pilchard eggs were possible during this project. First, sampling was done at the same 2 locations over a number of days in July to provide a measure of the daily variation in egg production occurring in one area (Table 3a).

The mean number of pilchard eggs found outside of King George Sound (Sites G1 \& G8) varied between
30 and 619 during the 5 d period of sampling, and from 5 to 1000 over all the samples taken during July. When only Day 1 eggs are used, the variation was reduced markedly to between 6 and 70 during the main sampling period (Table 3a).

A. further test examined the variation at the 8 sites that were sampled on different days in July (Table 3b). For both all eggs and Day 1 eggs, the values at the stations were similar with no significant difference found between days $\left(t_{\text {pair }}=1.13, \mathrm{p}>0.05, \mathrm{n}=8\right)$. Thus, there was a reasonable level of consistency in the abundance of eggs at sites on different sampling days. 


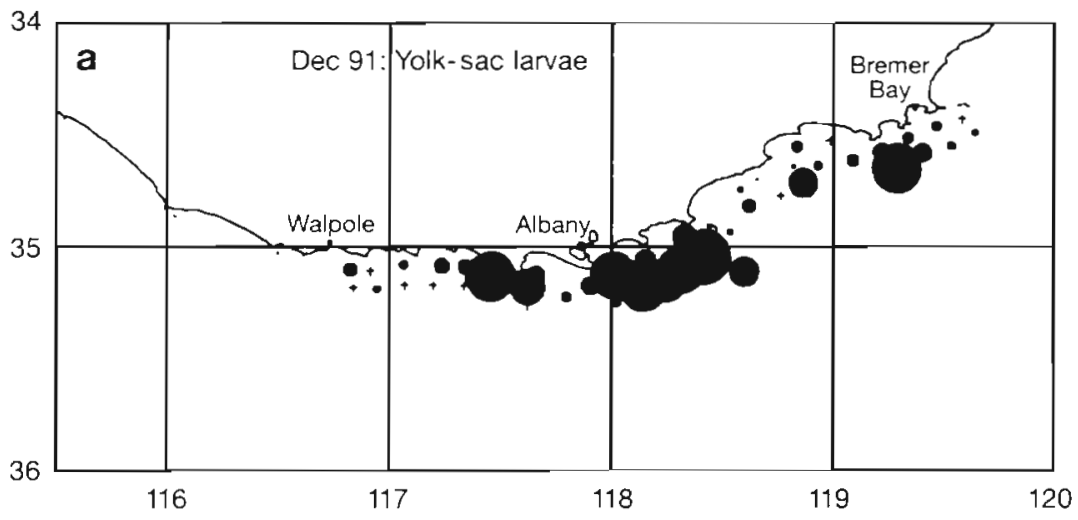

Nos $/ 200 m^{3}$
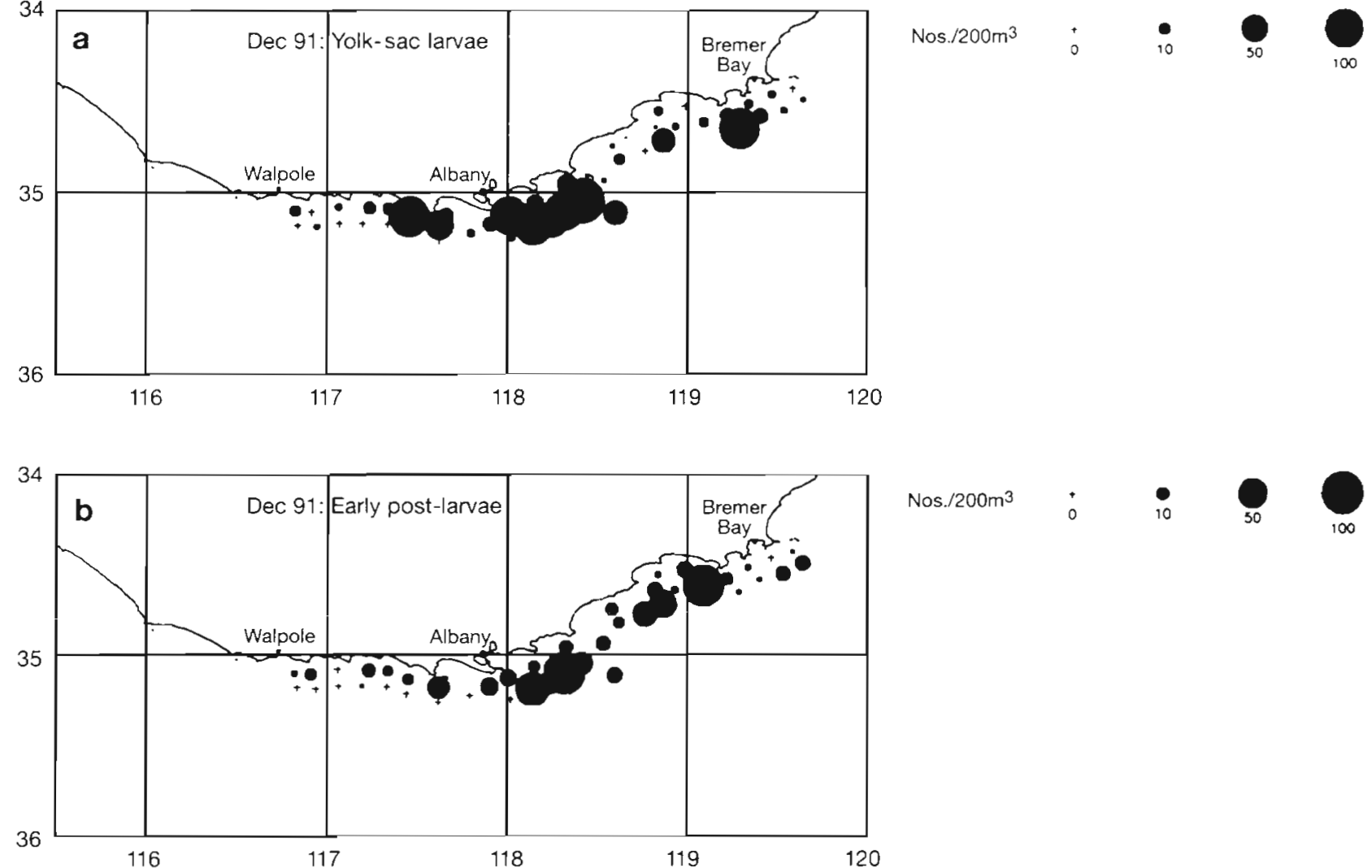

Nos. $/ 200 \mathrm{~m}^{3}$
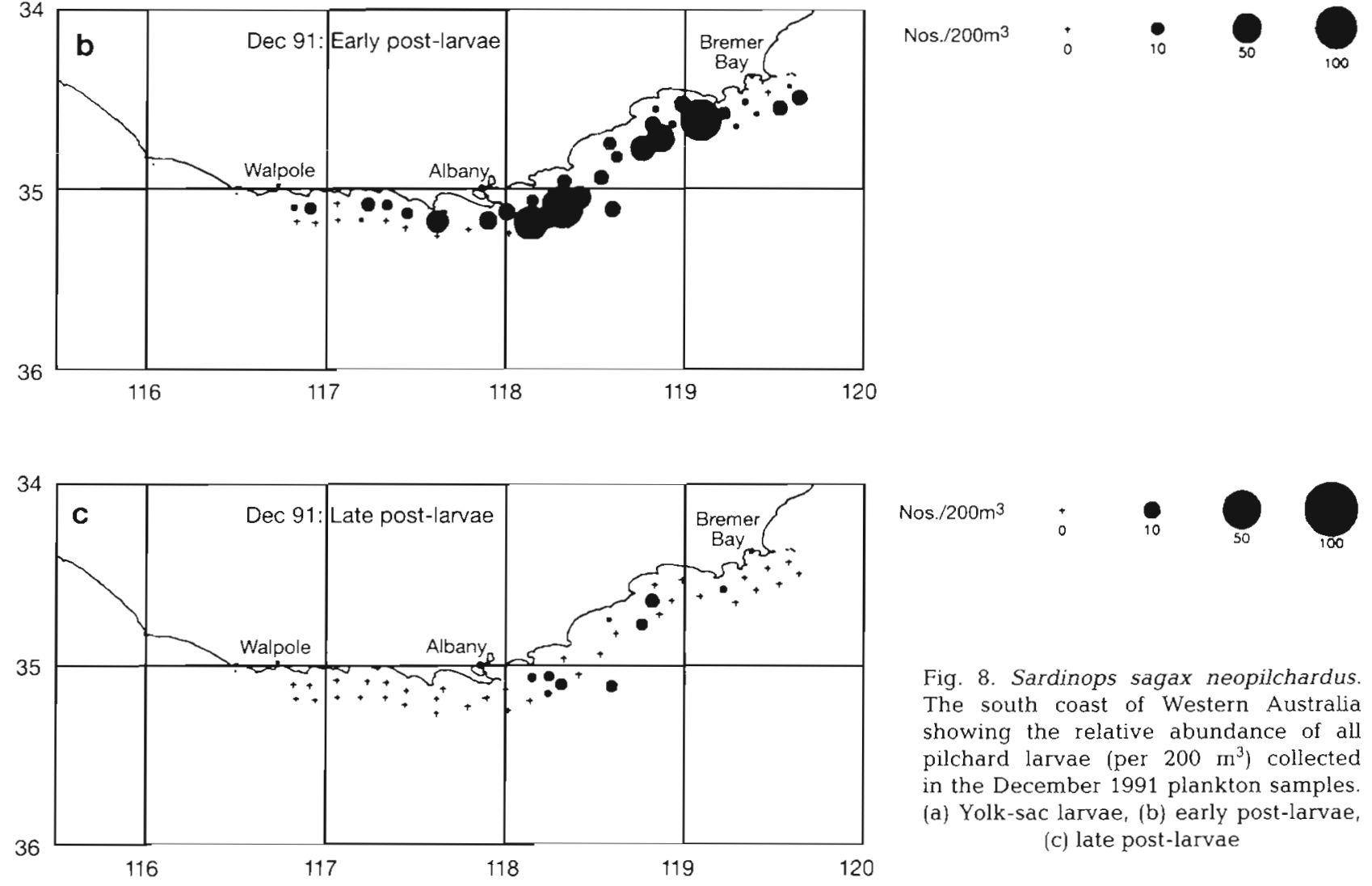

Nos. $/ 200 \mathrm{~m}^{3}$
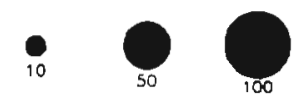

Fig. 8. Sardinops sagax neopilchardus. The south coast of Western Australia showing the relative abundance of all pilchard larvae (per $200 \mathrm{~m}^{3}$ ) collected in the December 1991 plankton samples. (a) Yolk-sac larvae, (b) early post-larvae, (c) late post-larvae

Finally, in December 2 samples were taken at the same site by the 2 different methods, vertical and oblique tows. This not only allowed a comparison of the small-scale variation in pilchard egg and larval numbers but also a comparison of the effectiveness of the vertical tow in relation to the more time-consuming oblique method. A total of 25 sites were sampled by both of these methods.

There was no significant difference in the overall abundance of pilchard eggs caught by the 2 methods (Table 4). Moreover, almost identical estimates of abundance were returned by both methods for each site, with both the slope and the $\mathrm{R}^{2}$ values close to unity (Fig. 9). There was no significant difference in the rates of capture of the Day 1 eggs between methods but with a tendency for less Day 1 eggs to be captured using the oblique hauls (Table 4). Conversely, there was a significant bias for the oblique tows to capture more Day 2 eggs than the vertical tows (Table 4). By contrast, the capture rate of larvae by the vertical tows was not only significantly higher than for the oblique tows (Table 4). but there was also no significant correlation between 
Table 2. Single-factor analysis of variance using a log transformation on the abundance of Day 1 eggs at the 8 blocks along the coast ( $\mathrm{D}$ to $\mathrm{K}$ ) sampled during the December 1991 tows. " $p<0.05$

\begin{tabular}{|lrrrr|}
\hline Source & df & SS & MS & $F$ \\
\hline Block & 7 & 10.80 & 1.5 & $3.0^{\circ}$ \\
Residual & 30 & 15.25 & 0.5 & \\
\hline
\end{tabular}

Table 3. Comparison of egg abundances (no. captured per $200 \mathrm{~m}^{3}$ ) at the same sites taken on different days for all eggs and Day 1 eggs. A: Area off King George Sound and overall mean number of eggs collected for the days when all 3 boats were operating. B: Samples taken at the same site on 2 different occasions by boats working east and west of Albany in July 1991

\begin{tabular}{|c|c|c|c|c|}
\hline \multirow[t]{2}{*}{$\begin{array}{l}\text { A } \\
\text { Date }\end{array}$} & \multicolumn{2}{|c|}{ KGS } & \multicolumn{2}{|c|}{ All sites } \\
\hline & All eggs D & Day 1 eggs & All eggs & Day 1 eggs \\
\hline 12 Jun & 10 & & & \\
\hline 14 Jul & 5 & & & \\
\hline 23 Jul & 1000 & 138 & & \\
\hline 25 Jul & 42 & 6 & 633 & 86 \\
\hline 26 Jul & 30 & 28 & & \\
\hline 27 Jul & 224 & 6 & 570 & 252 \\
\hline 28 Jul & 139 & 70 & 675 & 135 \\
\hline $29 \mathrm{Jul}$ & 619 & 28 & & \\
\hline \multicolumn{5}{|l|}{ B } \\
\hline \multirow[t]{2}{*}{ Site } & \multirow[t]{2}{*}{ Date } & \multicolumn{3}{|c|}{ Abundance } \\
\hline & & All & & ay 1 eggs \\
\hline G1 & $25 \mathrm{Jul}$ & 310 & & 15 \\
\hline G1 & $27 \mathrm{Jul}$ & 309 & & 12 \\
\hline G3 & $25 \mathrm{Jul}$ & 290 & & 0 \\
\hline G3 & $27 \mathrm{Jul}$ & 56 & & 0 \\
\hline G7 & $25 \mathrm{Jul}$ & 1100 & & 17 \\
\hline G7 & $27 \mathrm{Jul}$ & 3460 & & 3130 \\
\hline G8 & $25 \mathrm{Jul}$ & 1300 & & 1261 \\
\hline G8 & $27 \mathrm{Jul}$ & 139 & & 139 \\
\hline $\mathrm{H} 2$ & $25 \mathrm{Jul}$ & 1033 & & 78 \\
\hline $\mathrm{H} 2$ & $28 \mathrm{Jul}$ & 92 & & 62 \\
\hline $\mathrm{H} 7$ & $25 \mathrm{Jul}$ & 1322 & & 1143 \\
\hline $\mathrm{H7}$ & $27 \mathrm{Jul}$ & 7833 & & 1089 \\
\hline 13 & $25 \mathrm{Jul}$ & 2 & & 1 \\
\hline I3 & $28 \mathrm{Jul}$ & 3 & & 0 \\
\hline I4 & $25 \mathrm{Jul}$ & 1 & & 1 \\
\hline I4. & $28 \mathrm{Jul}$ & 10 & & 10 \\
\hline
\end{tabular}

Table 4. Comparison of catch rates (no. captured per $200 \mathrm{~m}^{3}$ ) of pilchard stages collected in oblique and vertical tows at the same site on the same day. NB: analysis performed on logtransformed data. ns: $\mathrm{p}>0.05 ;{ }^{*} \mathrm{p}<0.05 ;{ }^{*} \mathrm{p}<0.01$

\begin{tabular}{|lrrc|}
\hline & Oblique & Vertical & \multicolumn{1}{c|}{$t_{\text {parr }}$} \\
\hline All eggs & 121.5 & 105.0 & $1.05 \mathrm{~ns}$ \\
Day 1 eggs & 29.8 & 45.1 & $0.98 \mathrm{~ns}$ \\
Day 2 eggs & 91.7 & 60.0 & $3.20^{\circ}$ \\
Larvae & 13.0 & 42.8 & $2.58^{\circ}$ \\
\hline
\end{tabular}

the relative numbers of larvae caught at each site by the 2 methods (Fig. 9). Nonetheless, there was little difference in the overall patterns of abundance for larvae among blocks using either vertical or oblique tows (Fig. 5g, h).

\section{Influence of the Leeuwin Current}

$$
\text { July }
$$

An NOAA AVHRR (Advanced Very High Resolution Radiometry) thermal image taken of the south coast on 28 July 1991, during the middle of the plankton tow sampling period, clearly shows the distinct path of the Leeuwin Current as warm water flowing
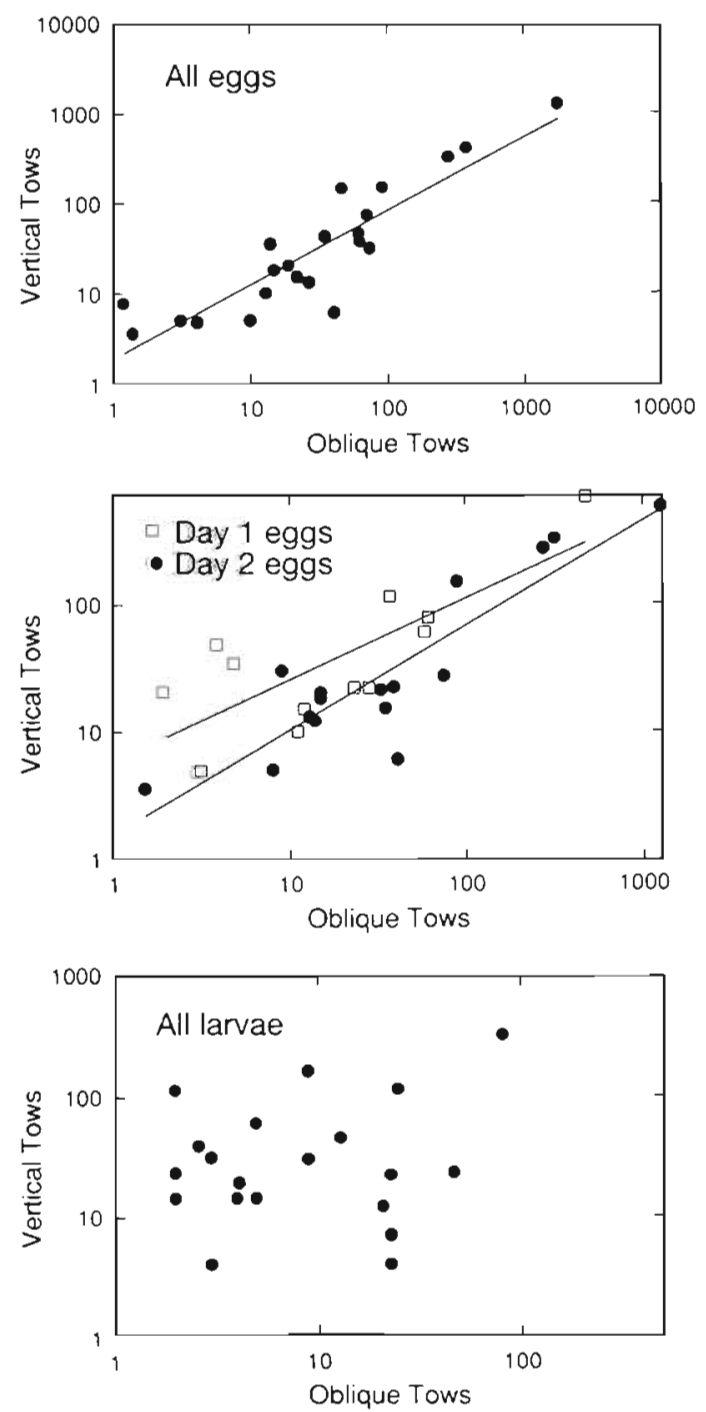

Fig. 9. Sardinops sagax neopilchardus. Relationships between the numbers of pilchard eggs and larvae collected in oblique and vertical tows at the same location 

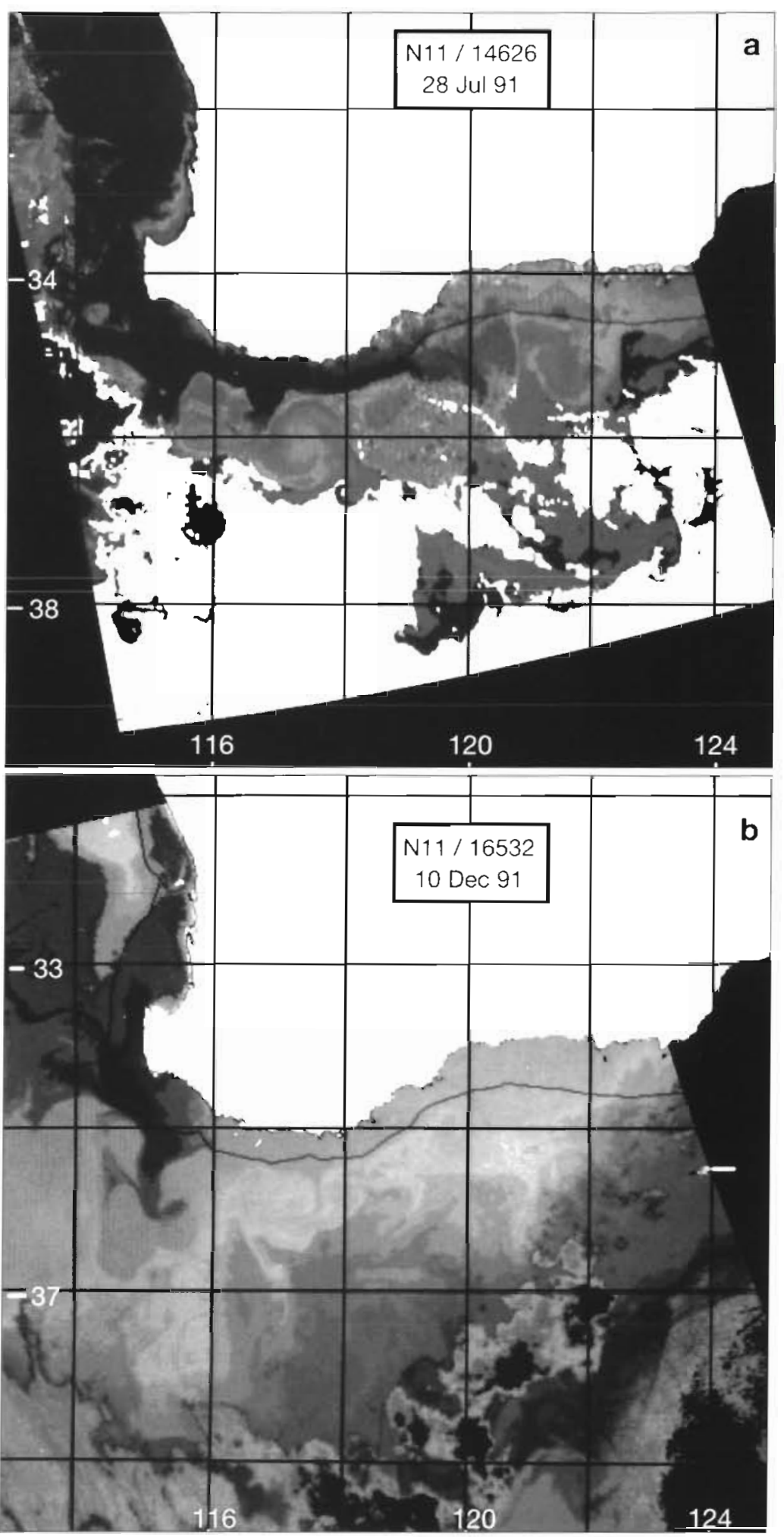

Fig. 10. NOAA advanced very high resolution radiometer thermal images of the south coast of Western Australia. The brightness temperature from band 4 is shown, with the warmest water in dark shades and cooler waters in pale tones; land is white. The rectangular grid is in latitude and longitude intervals of $1^{\circ}$. (a) 28 July 1991 (orbit N11/14626), (b) 15 December 1991 (orbit $\mathrm{N} 11 / 16532)$. The contour line indicates the $200 \mathrm{~m}$ isobath south along the west coast and east across the south coast (Fig. 10a). The warmest water $\left(18.5\right.$ to $20^{\circ} \mathrm{C}$ ), and presumably the strongest part of the current, was adjacent to the coast between Windy Harbour and Denmark (the region where there were very few pilchard eggs collected). East of Denmark, the current moved offshore to the edge of the continental shelf in the Albany region and was located off the edge of the shelf past Cape Riche (Fig. 10a). Thus, there was a band of cooler water $\left(17\right.$ to $\left.18.0^{\circ} \mathrm{C}\right)$ along the shelf area from Torbay to past Bremer Bay. This pattern was confirmed from temperature measurements taken during the tows (Fletcher et al. 1992).

The distribution of pilchard eggs appeared to be closely related to this current pattern, especially with the band of cooler water found inside the main influence of the Leeuwin Current (Fig. 10a). The plankton samples with large numbers of Day 1 eggs were all located near the boundary between the warm water and the cooler water, particularly in the region between Torbay and Cape Riche. This pattern produced a negative relationship between sea surface temperature and the abundance of pilchard eggs $(r=-0.36, n=77, p<0.05)$. This suggests that spawning was generally inshore of the main influence of the Leeuwin Current.

Despite the location of spawning, the longshore variation in the peak abundance of the various stages of pilchard eggs and larvae suggests that there was still a strong influence of an eastwards flowing current in the inner shelf regions during July (Fig. 5a). Thus, the consistent shift in the peaks of the different stages shows that there was movement of between 30 and $40 \mathrm{~km} \mathrm{~d}^{-1}$, until at least the early post-larval stage, corresponding to a current speed of 0.3 to $0.46 \mathrm{~m} \mathrm{~s}^{-1}$

\section{December}

The Leeuwin Current, whilst present, is much weaker during summer (Pearce 1991) and in December 1991 it appeared 
to greatly weaken in the region around Cape Leeuwin (Fig. 10b). Unlike winter, there was no clear band of warmer offshore water during summer with temperatures fairly uniform along the entire sampling region. Under these circumstances there was no obvious local oceanographic influence on the abundance of the pilchard eggs and consequently there was no significant relationship between egg abundance and sea surface temperature $(r=0.21, n=47, p>0.05)$.

The similar distributions for all the pilchard development stages are indicative of the weakness of the current at this time of the year. Thus, there was no difference in the location of the peaks in their abundance; the distributions of all pilchard stages (eggs and larvae) were centred around blocks $F$ to $H$ (Fig. 5e).

\section{DISCUSSION}

\section{Spawning distribution}

This study has provided an understanding of the pattern in the distribution and abundance of pilchard eggs and larvae along the south coast of Western Australia (W.A.). Numerous pilchard eggs and larvae were found along the south coast of W.A., further confirming that both July and December are periods of spawning activity of pilchards in this region (Fletcher \& Tregonning 1992). The distribution of the eggs, however, was not uniform over the entire sampled area, with large differences found in abundance among regions during both sampling periods. There appeared to be a major centre of spawning located off the Albany region and possibly a smaller centre (in winter at least) in the Bremer Bay region. This distribution is consistent with the pattern found for the number of acoustic marks found during July 1992 (Fletcher et al. 1992) which also showed concentrations off Albany and Bremer Bay. This result supports the assumption that the density of eggs is closely related to the density of adult pilchards.

The 2 main centres of pilchard spawning found during this study are, significantly, the 2 areas where the major pilchard fisheries are located in this region (Fletcher 1991). They are also characterised by major estuaries flowing into the ocean at these locations. Chesney \& Alonso-Noval (1989) found that the eggs of Sardina pilchardus off NW Spain were most abundant in regions where higher nutrients tended to occur. Similarly, Palomera (1992) found that anchovy spawning was centred around 2 major rivers flowing into the Mediterranean. It was postulated that these provided a better environment for the larvae due to the nutrient enrichment supplied by river discharge. Such outflows on the south coast of W.A. are probably the major source of nutrients to this region, which are generally lacking due to the influence of the oligotrophic Leeuwin Current (Pearce 1991). However in this instance this may be more important in providing food for the adults rather than the larvae.

The position of the Leeuwin Current during July appeared to have a direct effect on the location of pilchard spawning. Thus, in the Walpole region where the current was close to the coast, virtually no pilchard eggs were found. Instead, the majority of pilchard eggs were found in the cooler band of coastal water near Albany where the strongest part of the current had moved offshore to the edge of the continental shelf. Thus, most of the eggs were found in water of $18^{\circ} \mathrm{C}$, whereas the Leeuwin Current water was $19.5^{\circ} \mathrm{C}$ and above. In December, the Leeuwin Current, as expected (Cresswell 1991), appeared weaker and there was no dominant oceanographic feature off the south coast and consequently no major discontinuity in the distribution of pilchard eggs. Neither was there any significant relationship between water temperature and egg abundance as found during winter. Interestingly, there was little difference in the mean temperature of spawning (based on the areas where Day 1 eggs were found) between the winter and summer periods $\left(18.0\right.$ and $\left.18.8^{\circ} \mathrm{C}\right)$; King (1977) found that $18^{\circ} \mathrm{C}$ was the optimum temperature for the development of pilchard eggs off Namibia. Nonetheless, large numbers of dead eggs were found in the tows during July but not in December, a consistent phenomenon off Albany (Fletcher \& Tregonning 1992). It has not been determined whether the eggs die before or after capture (e.g. Moser \& Ahlstrom 1985) and thus conclusions concerning overall egg survival could not be made.

Despite the evidence that the main path of the Leeuwin Current during July was located near the edge of the shelf at Albany, and beyond the shelf at Bremer Bay, pilchard eggs were still mostly found at sites on the inner shelf region (up to $12 \mathrm{~km}$ from the coast). Few eggs were found in the mid-shelf regions, particularly near Albany, and whilst there were some in the mid-shelf region past Cape Riche, there were no pilchard eggs at the edge of the shelf near Bremer Bay. This pattern of pilchard eggs being found predominantly close to the coast is identical to that found in the previous study of pilchard spawning off Albany (Fletcher \& Tregonning 1992). There is some evidence that the offshore extent of spawning away from the immediate Albany area was greater during December, but there were insufficient tows in the mid-shelf region to confirm this. This inshore pattern of spawning is consistent with those for other populations of Sardinops, particularly when they are in small biomass phases (Lluch-Belda et al. 1989, Kuroda 1991). 


\section{Sampling efficiency}

The reliability of the patterns of pilchard eggs abundance found in this study was increased by the use of several boats. This method greatly reduced the time taken to complete sampling, providing a 'snap-shot' picture of egg abundance rather than one influenced by temporal variations. Using several boats enabled sites that were quite distant from each other to be sampled on the same day, thereby significantly reducing the risk that any apparent longshore patterns of abundance were merely due to daily differences in spawning. Finally, a number of sites were sampled more than once on the same and different days, providing data on spatial and daily variability. The analysis of these data indicated that although there was some variation between days in the numbers of eggs found at a site, in general the numbers of eggs collected at a site were reasonably stable, at least during the week of sampling. Furthermore, consecutive tows at the same location showed that egg abundance does not vary significantly over small spatial scales and that the short, simple vertical tows are as effective in sampling the eggs as are longer oblique tows.

One possible complication to the reliability in the pattern of egg abundance was that the numbers of Day 1 eggs were lower than the numbers of Day 2 eggs in both series, which is the opposite to that expected. This could indicate that our ageing of the eggs was incorrect and that they may not hatch for $3 \mathrm{~d}$. However, this is unlikely given the consistency of egg development times among different studies in different areas (Tibby 1937, Baker 1972, King 1977) which all suggest development of pilchard eggs at $18^{\circ} \mathrm{C}$ takes just $2 \mathrm{~d}$. Furthermore, there were only 2 peaks found in the egg stages and the majority $(80 \%)$ of Day 2 eggs were stages 11 or 12 which are only a few hours apart. Another possible limitation is that our towing methods were not sampling the Day 1 eggs effectively, with perhaps Day 1 eggs being deeper than $50 \mathrm{~m}$. If so, this would be contrary to studies which have found that pilchard eggs tend to be distributed above $50 \mathrm{~m}$ and are generally close to the surface (Ahlstrom 1959). Nonetheless, the differences that were found in the relative numbers of 1 and $2 \mathrm{~d}$ old eggs between oblique and vertical tows done at the same sites suggest that this aspect should be investigated further.

An alternative explanation is that the spatial distribution of the Day 1 eggs was more contiguous than later stages due to spawning occurring in discrete patches. There is some evidence for this with the coefficient of variation for Day 1 eggs being the highest of all stages, decreasing with age (as diffusion occurs) down to postlarvae. This pattern has been found in other similar plankton studies (Smith \& Hewitt 1985).

\section{Transport}

The variation in the longshore distribution of the planktonic pilchard stages during July was consistent with a relatively strong easterly movement of between 0.5 and 1.0 knot. This rate was similar to that found by Cresswell (1991) on the shelf near Albany region for the warm, low-nutrient Leeuwin Current. Easterly advection along the shelf explains the lack of larvae found in the Albany region during July of both 1989 and 1990 in the previous study done off King George Sound by Fletcher \& Tregonning (1992), who postulated that either mortality or movement of eggs and larvae at this time of year must be large. Substantial transport away from the area of spawning has been found in many clupeid species (Heath 1992), but, unlike the situation off Albany, this is usually associated with cold, upwelling currents which result in the larvae being moved to highly productive nursery areas (e.g. Engraulis capensis; Shelton \& Hutchings 1982). Such a fundamental difference in the properties of currents which influence the location of spawning and subsequent survival can have a profound effect on the relative size of populations. Thus, while clupeid stocks influenced by currents within upwelling areas often achieve biomass levels in excess of a million tonnes (Lluch-Belda et al. 1989), the pilchard stock off the Albany region is constrained to significantly smaller levels (Fletcher et al. 1992).

The movement of the pilchard stages away from Albany across to the Bremer Bay region during July makes it unlikely that these 2 areas could be reproductively isolated. Nevertheless, given that there were 2 centres of spawning in July, the possibility remains that they could function separately as adult populations, as was assumed in the spatial model built to simulate the fishery off Albany (Fletcher 1992). There are some additional micro-chemical (Edmonds et al. 1994) and catch-at-age data (Fletcher unpubl.) which also support this hypothesis. This endorses Sinclairs' (1988) concept that it is the geographical discontinuities of the early life stages, rather than of the adults, which defines population structure.

The variation in the extent of drift experienced by the pilchard stages between the 2 spawning periods is rare. This disparity would impose a large difference on the life histories of individuals spawned between the 2 periods. It raises the possibility that there could be 2 genetically isolated stocks occupying the same general area, a summer-and a winter-spawning stock similar to the autumn- and spring-spawning herring stocks (see Sinclair 1988 for review). Electrophoretic studies have shown that there are genetic differences among pilchards captured in King George Sound at different times of the year (Dixon et al. 1993) but no 
consistent pattern has yet emerged. Investigations are continuing.

The difference in transport found among seasons also highlights a potential problem in any similar ichthyoplankton studies that fail to identify egg stages. Very different conclusions concerning the possible structure of this population could have been drawn from this study if only the distribution of larvae had been used and to some extent even if only the distribution of un-aged eggs had been used. Furthermore, the ability to identify and age eggs, and therefore determine each of their distributions, permits the spawning area of pilchards within this region to be identified and measured. This, together with data on the spawning dynamics of the adults, has allowed the first estimates of the spawning biomass for the region to be made (Fletcher et al. 1992). With this information, our knowledge of the population size and structure of W.A. pilchards has increased greatly and our ability to manage the fishery has, therefore, been greatly enhanced.

Acknowledgements. This study was financed by grants from the Australian Government Department of Primary Industry's Fishing Industry Research and Development Council (FIRDC project No. 91/24) and from the Fishing Industry Research Trust account of Western Australia. This study would not have been possible without the assistance of the south coast fishermen, Messrs Palfrey, Gray, Pike and Westerberg who provided their boats and experience at reduced costs to assist with this sampling. Thanks must also go to the local Fisheries Department inspectors who helped greatly with the plankton sampling in Albany. Alan Pearce of the CSIRO Division of Oceanography kindly provided the NOAA sea surface images and helped with their interpretation. Finally the manuscript was aided by comments from staff of the Western Australian Marine Research Laboratories.

\section{LITERATURE CITED}

Ahlstrom, E. H. (1959). Sardine eggs and larvae and other fish larvae of the Pacific coast, 1957. U.S. Fish. Wildl. Serv. Spec. Sci. Rep. Fish. 328: 1-99

Baker, A. N. (1972). Reproduction, early life history, and age-growth relationships of the New Zealand pilchard, Sardinops neopilchardus (Steindachner). Fisheries Res. Div. N.Z., Fish. Res. Bull. No. 5

Chesney, E. J., Alonso-Noval, M. (1989). Coastal upwelling and the early life history of sardines (Sardina pilchardus) along the Galician coast of Spain. Rapp. P.-v. Réun. Cons. int. Explor. Mer 191: 63-69

Cresswell, G. R. (1991). The Leeuwin Current. Observations and recent models. J. R. Soc. West. Aust. 74: 1-14

Cushing, D. H. (1988). The migration of larval and juvenile fish from spawning ground to nursery ground. J. Cons. int. Explor. Mer 43: 43-49

Cushing, D. H. (1990). Plankton production and year-class strength in fish populations: an update of the match/mismatch hypothesis. Adv, mar. Biol. 26: 249-293

Dixon, P. I., Worland, L. J., Chan, B. H. Y. (1993). Stock identification and discrimination of pilchards in Australian waters, using genetic criteria. Final report 89/25, Fishing Industry Research Trust Council, Canberra
Edmonds, J. S., Caputi, N., Moran, M. J., Fletcher, W. J., Morita, M. (1994). Minor and trace elements in teleost sagittal otoliths and their use for population discrimination. In: Secor, D. H., Dean, J. H., Campana, S. E. (eds.) Recent developments in fish otolith research. Univ. South Carolina Press, Columbia (in press)

Fletcher, W. J. (1991). A synopsis of the biology and exploitation of the Australasian pilchard, Sardinops neopilchardus (Steindachner), Part II, History of stock assessment and exploitation. Fish. Res. Rep. Fish. Dept W.A. 91: 1-55

Fletcher, W. J. (1992). Use of a spatial model to provide initial estimates of stock size for a purse seine fishery on pilchards (Sardinops sagax neopilchardus) in Western Australia. Fish. Res. 14: 41-57

Fletcher, W. J., Tregonning, R. J. (1992). The distribution and timing of spawning by the Australian pilchard (Sardinops sagax neopilchardus) off Albany, Western Australia. Aust. J. mar. Freshwat. Res. 46: 1437-1449

Fletcher, W. J., Tregonning, R. J., Sant, G. J., Blight, S. J., Rossbach, M. H. (1992). Investigation of the abundance and distribution of pilchard eggs and larvae off southern Western Australia. Final report, FIRDC Project 91/24, Fishing Industry Research Development Council, Canberra

Heath, M. (1992). Field investigations of the early life stages of marine fish. Adv. mar. Biol. 28: 1-174

Iles, T. D., Sinclair, M. (1982). Atlantic herring: stock discreteness and abundance. Science 215: 627-633

Kasai, A., Kishi, M. J., Sugimoto, $\Upsilon$. (1992). Modeling the transport and survival of Japanese sardine larvae in and around the Kuroshio current. Fish. Oceanogr. 1: 1-10

King, D. P. F. (1977). Influence of temperature, dissolved oxygen and salinity on incubation and early larval development of the South West African pilchard Sardinops ocellata. Investl Rep. Sea Fish. Branch S. Afr. 114: 1-35

Kondo, K. (1988). On the mode of distribution and migration of the Japanese sardine, Sardinops melanostictus (Temminck \& Schlegel), at high level stock size. Bull. Tokai reg. Fish. Res. Lab. 124: 1-33

Kuroda, K. (1991). Studies on the recruitment process focusing on the early life history of the Japanese sardine, Sardinops melanostictus (Schlegel). Bull. natn. Res. Inst. Fish. Sci. 3: 25-278

Lluch-Belda, D., Crawford, R. J. M., Kawasaki, T., MacCall, A. D., Parrish, R. H., Schwartzlose, R. A., Smith, P. E. (1989). World-wide fluctuations of sardine and anchovy stocks: the regime problem. S. Afr. J. mar. Sci. 8: 195-205

Moser, H. G., Ahlstrom, E. H. (1985). Staging anchovy eggs. In: Lasker, R. (ed.) An egg production method for estimating spawning biomass of pelagic fish: application to the northern anchovy. Engraulis mordax. NOAA Tech Rep NMFS 36: $37-42$

Moser, H. G., Smith, P. E. (1993). Larval fish assemblages and oceanic boundaries. Bull. mar. Sci. 53: 283-289

Nakata, H., Hasanuma, K., Hirano, T. (1989). Distribution of sardine eggs and larvae related to the surface circulation in Sagami Bay. J. Oceanogr. Soc. Japan 45: 11-23

Nelson, W. R., Ingham, M. C., Schaaf, W. E. (1977). Larval transport and year-class strength of Atlantic menhaden, Brevoortia tyrannus. Fish. Bull. U.S. 75: 23-41

Norcross, B. L., Shaw, R. F. (1984). Oceanic and estuarine transport of fish eggs and larvae: a review. Trans. Am. Fish. Soc. 113: 153-165

Palomera, I. (1992). Spawning of anchovy Engraulis encrasicholus in the northwestern Mediterranean relative to hydrographic features in the region. Mar. Ecol. Prog. Ser. 79: $215-223$ 
Pearce, A. F. (1991). Eastern boundary currents of the southern hemisphere. J. R. Soc. West. Aust. 74: 35-46

SAS Inst. (1987). SAS/Stat users guide. SAS, Cary, NC

Shelton, P. A., Hutchings, L. (1982). Transport of anchovy Engraulis capensis Gilchrist, eggs and larvae by a frontal jet current. J. Cons. 40: 185-198

Sinclair, M. (1988). Marine populations: an essay on population regulation and speciation. Wash. Sea Grant. Univ Wash. Press, Seattle

Smith, P. E., Hewitt, R. P. (1985). Anchovy egg dispersal and mortality as inferred from close-interval observations.

This article was submitted to the editor
Calif. coop. Oceanic Fish. Invest. Rep. 26: 97-109

Smith, P. E., Richardson, S. L. (1977). Standard techniques for pelagic fish egg and larva surveys. F.A.O. Fish. tech. Pap. 175: $1-100$

Syahailatua, A. (1992). The Australian pilchard (Sardinops neopilchardus), morphometric, meristic, growth, and reproductive studies. M.Sc. thesis, Univ. N.S.W., Sydney

Tibby, R. B. (1937). The relation between surface water temperature and the distribution of spawn of the California sardine Sardinops caerulea. Calif. Fish Game 23: $132-137$

Manuscript first received: February 7, 1994

Revised version accepted: May 26, 1994 